\title{
Panel Analysis of the Relationship Between Weather Variability and Sectoral Output in Kenya
}

\author{
Olga Nekesa Mulama and Caroline Wanjiru Kariuki
}

\section{Contents}

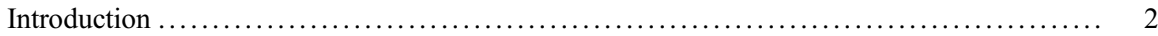

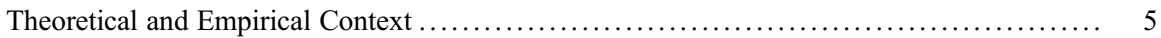

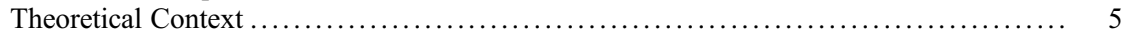

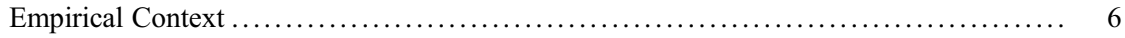

Interactions Between the Variables Used in This Research ....................... 8

Approach to Identify the Relationship Between Weather Variability and Sectoral Output .... 9

Data Collected ...................................................... 9

Model on the Relationship Between Weather Variability and Sectoral Output .......... 10

Procedure .......................................................... 11

Establishing the Relationship Between Weather Variability and Sectoral Output ........... 11

Unit Root Test ...................................................... 11

Long-Run Relationship Between Temperature and Sectoral Output ................. 12

Effect of Weather Variability on Sectoral Output ............................. 12

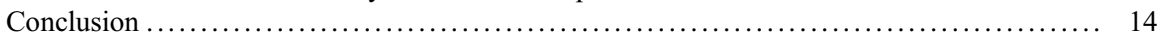

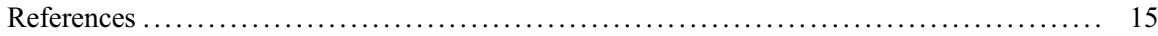

\section{Abstract}

Climate change and economic growth are closely connected. Climate change has the potential to reduce economic growth in developing countries due to their limited ability to respond to the negative impacts of a changing climate. A better understanding of weather variability can enhance climate change policies, which would help to support economic growth in these countries. As such, this research

This chapter was previously published non-open access with exclusive rights reserved by the Publisher. It has been changed retrospectively to open access under a CC BY 4.0 license and the copyright holder is "The Author(s)". For further details, please see the license information at the end of the chapter.

O. N. Mulama $\cdot$ C. W. Kariuki $(\bowtie)$

Strathmore Institute of Mathematical Sciences, Nairobi, Kenya

e-mail: olga.mulama@strathmore.edu; cwkariuki@strathmore.edu 
sought to examine if there is a long-run relationship between sectoral output and weather variables (temperature and rainfall) and to analyze the effect of weather variability on sectoral output using a panel of 13 sectors in Kenya.

A Pedroni cointegration test was carried out to find out if there exists a longrun relationship among the variables and thereafter, a fully modified ordinary least squares regression was conducted to establish the effect of weather variability on sectoral output. The results indicate that there is a long-run relationship between temperature and sectoral output. Moreover, temperature has a larger effect on sectoral output compared to rainfall. With the evidence gathered from this research, it can be concluded that weather variability has an economic effect on sectoral output in Kenya. Given this, the Kenyan government needs to take a keen interest in understanding the effect of weather variability on the economy and in the broader picture, take steps to mitigate climate change.

\section{Keywords}

Weather variability $\cdot$ Climate change $\cdot$ Temperature $\cdot$ Rainfall $\cdot$ Sectoral output $\cdot$ Economic growth $\cdot$ Kenya $\cdot$ Panel data $\cdot$ Cointegration $\cdot$ Fully modified OLS

\section{Introduction}

Weather refers to the temporary conditions of the atmosphere, which is the layer of air that surrounds the earth. There are various factors that can change the atmosphere such as temperature, air pressure, humidity, wind speed, wind direction, altitude, and topography, among others. Together, these factors determine the weather in a certain area (National Centers for Environmental Information 2018). On the other hand, climate refers to the state of the weather over a long period of time in a specific area. Predictable weather is important for social and economic planning as it results in sustainable development. However, climate change could affect health, infrastructure, transportation systems, as well as energy and food supplies. There is also a global challenge of acute water scarcity, which can be attributed to the extreme temperatures. On a global scale, there is a cry for environmental conservation since extreme weather occurrences have been found to be directly linked to the environment's state. Through their research, Mortimore et al. (2009) provide insight on the pattern that developing countries have recorded in terms of extreme weather occurrences. The authors find that there has not been much investment and development to aid in preventing the damages that come with extreme weather occurrences in these countries. Developing countries are currently faced with considerable development constraints and to top it off, their poor coping and adaptation strategies to a changing environment push them deeper into development issues. The agricultural, livestock, fisheries, tourism, energy, forestry, health, and water sectors usually take the biggest blow when extreme weather events take place due to their relation and dependent nature on weather. The labor force and industries are also affected due to extreme weather events and this eventually ends up having an adverse effect on the peace and stability of a country. 
In Kenya, the country's wildlife and other tourist attractions are vulnerable to the impact of climate change. Ferrara's (2015) research revealed that tourism in Kenya would be significantly affected by a change in wildlife migration patterns (e.g., wildebeest migration) caused by changing weather. Consequently, this would have a negative effect on the country's economy given that tourism is one of the major contributors to Kenya's Gross Domestic Product (GDP). Mount Kenya, which is another major tourist attraction, has snowcaps that are melting due to increased global temperatures. Additionally, the Kenyan economy is highly dependent on agriculture which contributes approximately $33 \%$ to the nation's GDP. The agricultural sector in Kenya employs about $40 \%$ of the total population with more than $70 \%$ coming from rural areas (Food and Agriculture Organization 2019). The Food and Agriculture Organization ( 2019) also reports that farmers who are used to rain-fed farming systems are being pushed to areas that are vulnerable to drought due to increased human population. Furthermore, the unpredictability of weather patterns resulting from climate change does not favor their farming practices. In many developing countries, households face difficulty in adapting to climate change and very few households make a step and change their farming practices in response to climate change. Okoba et al. (2013) argue that despite the possibility to change this, many households are unable to make the costly investment and join the bandwagon in the agricultural shift. Despite developing countries having information on extreme weather occurrences, the impact of the occurrence of an extreme weather event is still very high. News of extreme weather patterns across Africa is increasingly becoming frequent and policymakers can no longer overlook this effect, which is a result of climate change. As temperatures continue to rise as a result of global warming, there are bound to be water shortages in Africa causing droughts and in the short term, occurrences of flash floods as well. The cycle effect is that agricultural output will be affected thus causing a drop in rural incomes for farmers who depend on agriculture and resulting in a decline in consumption and investment.

Evidently, climate and agriculture are highly correlated as discussed by Linke et al. (2015) who carried out a research on the relationship between climate and social instability in Kenya. Agriculture is highly dependent on favorable weather conditions. Low output from farming during unfavorable weather conditions would result in low returns on the farmers' investment and in the next agricultural season, farmers may not have enough capital to invest for their next harvest. This is a vicious cycle whereby output that is affected by the weather would affect levels of income and this in turn affects the input necessary to produce more and the cycle continues. Dell et al. (2012) seek to bring out the evidence that in fact weather and economic variables do have a direct relationship. Their research examined the relationship between temperature shocks and economic growth in both rich and poor countries. Their findings show that higher temperatures reduce agricultural output, industrial output, and political stability. Not only do changes in the weather affect the agricultural and industrial sectors of a country, but the health of the population as well. The general health of a population is usually at risk in cases of extreme weather occurrences like drought and floods. In Kenya, infectious disease outbreaks such as waterborne, rodent-borne, and vector-borne diseases have been associated with flooding especially in areas with poor drainage systems (Okaka and Odhiambo 2018). Moreover, 
being on the equator, the temperate climate provides a perfect breeding ground for mosquitoes that spread malaria. Yanda and Mubaya (2011) report a rise in mosquito population in the occurrence of erratic weather where the spread of malaria and other waterborne diseases causes Kenya's income to shrink in affected areas. This is because the current labor force must attend to their sick family members and current and/or future labor force could also decrease should they succumb to diseases. Furthermore, the World Health Organization (2018) reports that diseases transmitted by insects are emerging and reemerging and epidemics are reported more frequently than before in Africa. Evidence points to climate change being a major contributor to this public health crisis. With the weak adaptive mechanisms in developing nations, adverse weather patterns are bound to have a huge impact on the entire economy affecting the majority of the population. Thus, there is a need for policymakers to plan accordingly and most especially conserve the environment and thus the economy for future generations. The erratic nature of weather patterns without adequate adaptation mechanisms has cost Kenya much more than it would have cost the country to put in place preventative measures that would reduce the scale of damage. For example, During the El Niño that occurred in 1997, Kenya made losses of up to USD one billion (Ngecŭ and Mathu 1999). The lack of preparation in the country adversely affected physical infrastructure due to the heavy downpour and further affected road, air, and rail transport networks.

Given this, Nyangena (2016) studied the impact of weather variability (rainfall and temperature) on economic growth in Kenya. Nyangena (2016) cited the need for further empirical explorations and as such, this research analyzed the effect of weather (temperature and rainfall) variability on sectoral output in Kenya using panel data. Specifically, this research sought to establish if there is a long-run relationship between temperature, rainfall, and sectoral output in Kenya and to determine the effect of temperature and rainfall on sectoral output in Kenya. The sectors captured in this research were agriculture and forestry; mining and quarrying; manufacturing; electricity and water; construction; wholesale and retail trade; hotels and restaurants; transport and communication; financial intermediation; real estate, renting, and business services; public administration; education; and other services.

It is important to remember the past so as to model better decisions for the future. Consequently, this chapter will make a contribution to literature by providing a deeper understanding of the effect of weather variability on economic output in Kenya using historical data. This will ultimately aid policymakers in planning and making decisions that will have a positive effect on the welfare of future generations. More specifically, the findings from this research will provide further insights on the effect of weather (temperature and rainfall) variability on sectors that contribute to Kenya's economic growth. Further, the results will assist environmentalists in campaigning for environmental conservation and promote the use of environmentally friendly products, methods, and clean energy. Institutions such as The National Environment Management Authority of Kenya and the Green Belt Movement together with the Ministry of Environment and Natural Resources and are not only involved in environmental campaigns but also advocate for policies and strategies that will help conserve the environment and mitigate the effects of climate change. The Ministry of Agriculture also stands to make more informed decisions that will 
benefit farmers and offer insight on policies regarding food security in Kenya related to weather variability.

\section{Theoretical and Empirical Context}

\section{Theoretical Context}

\section{Chaos Theory}

Making future weather forecasts is hard. It is only predictable to forecast the weather behavior in the future when a trend is observed from some initial weather conditions. Stephens et al. (2012) state that it is easier to predict climate than weather because weather is governed by an imbalance of the world's energy forces. A chaotic system is purely deterministic assuming absolute dynamism to the extent of exhibiting unpredictability in standard statistical tests, rendering it chaotic. Chaos theory, as described by Lorenz (1963) is the confusion, disorder, unpredictability, turbulence, and uncertainty in a spectrum of things. A chaotic system is one that is affected by initial occurrences and dynamic nonlinear patterns that are not fundamentally random. Understanding the initial points is fundamental for predictability to hold. Weather patterns are nearly impossible to predict due to their chaotic nature. However, with the advent of computers and their ability to handle massive amounts of data, there is a better possibility of predicting the weather. An essential observation would be to see how many times the weather predictions have merged with the actual weather occurrences. As observed from past weather occurrences, there is generally a disparity most times and this is attributed to the possibility of climate change taking place. A general standard stochastic test can be useful in distinguishing a set of randomness and chaos.

\section{Climate Change Theories}

Hulme (2009) describes climate science as a function of the limits of science itself. Mathematicians working on climate systems find that uncertainties in climate prediction arise not only from initial conditions and forcing scenarios but also from model formulation. Further, the anthropogenic global warming theory admits that the climate system is naturally chaotic. Most people are familiar with anthropogenic global warming, which is manmade global warming. Under the theory of anthropogenic global warming, it holds that manmade greenhouse gases are the main cause of global warming that has occurred during the past 50 years. As the years have progressed, loopholes have been found in this theory and new evidence shows that other natural factors contribute to modern global warming. The theory of anthropogenic global warming is contested by other theories, some of which include the theory of the Bio-thermostat, which claims negative feedback from biological and chemical processes offset whatever positive feedback might be caused by the rising carbon dioxide levels (Idso and Singer 2009). Sud et al. (1999) observed cloud coverage and formation. They found that the cloud coverage acted as a thermostat to regulate sea surface temperatures to a temperature of $28^{\circ} \mathrm{C}$ and $30^{\circ} \mathrm{C}$. In a separate theory on human forcing, Matsui and Pielke (2006) explain that human activities 
such as deforestation, aerosols and ozone, coastal development, and jet contrails (the trail left behind by jets) transform the earth's surface. Additionally, carbon dioxide emissions as a result of human activities play a dominant role on long-term climate change. The US Global Change Research Program (2014) reports changes in the earth's climate due to the earth warming, with a key indicator of climate change being extreme weather and climate events.

\section{Economic Growth}

The neoclassical theory on economic growth states that the stock of capital, supply of labor, and technological developments are factors that affect the growth of an economy. The theory further explains the law of diminishing returns where increasing capital and labor have a limited impact on increasing economic growth. The new economic growth theories criticized the neoclassical theories stating that labor productivity does not have diminishing returns but rather has increasing returns and emphasis is put on the type of capital investment. Smith (1776) emphasized the dependency of economic growth on labor efficiency through division of labor. Additionally, Montesquieu and De Secondat (1748) argued that excess heat made men slothful and dispirited. As such, adverse climatic conditions affect laborers' well-being and this in turn affects their output ultimately affecting economic growth. Moreover, the Malthus theory predicts that economic growth may have limitations caused by changes in the climate, overpopulation, and scarcity of resources.

In his earlier studies, Barro (1999) explains that the growth rate of real per capita GDP was associated with higher levels of schooling. This is because an additional year in school enhances workforce capability to work and increases productivity. Real GDP per capita as used in this context is the measure of the economy's total output in a country divided by the population and further adjusted for inflation. Workers level of education is a measure of human capital and is directly related to productivity. Under the Harrod-Domar theory, capital formation is given more weight on its effect on economic growth. The Harrod-Domar theory emphasizes the importance of national savings and productivity of capital investment as central to economic growth. The growth of an economy is dependent on demand created from newly generated income such that output produced by new investments can be fully absorbed. Ultimately, this should increase the production capacity of the economy. This theory further assumes that labor and capital are complementary to each other.

\section{Empirical Context}

A report by the Intergovernmental Panel on Climate Change (2014) warned that global temperatures are expected to increase by an estimate of $4{ }^{\circ} \mathrm{C}$ by 2100 (World Bank 2012). Considering these projections, economists and policymakers are faced with the need to quantify the impact of weather patterns, specifically rising temperatures on economic activity. Nordhaus (2010) cites the significant effects of extreme weather events on the level of the US GDP. According to Dell et al. (2012), in their analysis of the relationship between temperatures and aggregate economic activity, hot countries 
tend to be poor, with national income falling $8.5 \%$ per degree Celsius in the world cross-section. With the recent interest in climate change, it is a matter of concern to understand the impact of the weather on all aspects of life. Colacito et al. (2019) estimated the effect of temperature on the growth rate of US GDP using a panel of the US states. From their estimates, they concluded that if the current trend in rising temperatures does not change, then a drop of economic growth by up to one third could occur. Further, in their estimation, they found that summer and fall exhibited opposite signs. Summer and fall had opposite effects on the US Gross State Product (GSP). This meant that rising temperatures during summer decreased economic growth as estimated by GSP and a significant rise during fall as the temperatures decreased. There has been a difficulty in concluding the general effect of weather patterns using annual data as each year presents different seasons. This heterogeneous effect can be dealt with by using more frequent data to represent the weather patterns.

In their inquiry, Linke et al. (2015) speculated that the future will get warmer, wetter, and wilder climates will be experienced. Ultimately, there is and still will be a surge of migrants and new wars. Intercommunity battles for resources increase conflicts and violence driven by calculation and political gain. According to the Food and Agriculture Organization of the United Nations (2019), increased competition for natural resources in Kenya has sparked escalated conflicts in some of the areas. Abidoye and Odusola (2015) examined the link between economic growth and climate change and found that the vulnerability of most African economies to climate change is of concern. A fair majority of the working population largely depend on informal employment in economic sectors that are sensitive to climate change (such as agriculture, forestry, energy, tourism, coastal, and water resources). Temperature was seen to have a negative impact on GDP growth where a $1{ }^{\circ} \mathrm{C}$ change in temperature would result in an inverse change in GDP growth by $0.67 \%$. Given this, there is a need to manage the impact of climate change on Africa's economy to ensure developmental growth. In another article, Deryugina and Hsiang (2014) explored within-country variation in the United States and found that daily temperature above certain thresholds $\left(15^{\circ} \mathrm{C}\right.$ and $\left.30{ }^{\circ} \mathrm{C}\right)$ reduces the productivity level. In a related paper, Zivin and Neidell (2014) find that warmer temperatures reduce labor supply in the United States, thus providing an economic rationale for why climate change might affect economic activity in a developed economy. There has been a correlation between poverty and heat as suggested by Montesquieu and De Secondat (1748), who argue that excess heat made men slothful and dispirited.

Several other studies have focused on agriculture specifically and there is an evident inverse relationship between agricultural productivity and extreme weather occurrences although this is dependent on the crop type. Beyond agricultural constraints as a result of climate change, Awuor et al. (2008) found that floods lead to serious loss of life and property, which coastal towns such as Mombasa face as a result of climate change. Mombasa is a major contributor to Kenya's GDP through tourism, industries, imports, and exports and serves both Kenya and landlocked countries around it. Floods lead to loss of life, displacement of people, and destruction of infrastructure. Floods can occur at any time despite weather or climate patterns influencing when and where these floods occur (Smith 2002). Although 
drought affects more people than floods do, disease outbreaks such as malaria, typhoid, bilharzia, and dysentery have been seen to cripple labor productivity. Flood disasters are associated with the presence of flood hazards due to the nature of the terrain or flood vulnerability, which is attributed to poor regulation, poor land use, degradation of water catchment areas, poverty, population pressures, and settlement patterns (Opere 2013).

In a more recent research done in Kenya, Nyangena (2016) explored the relationship between GDP per capita, annual temperature changes, and annual rainfall and found that a unit change in temperature resulted in approximately 142 times change in GDP per capita arguing that temperature has a greater effect on GDP than rainfall. The empirical literature in Kenya revealed some inconsistencies with other bodies of literature that have sought out to explore the role of weather and climate changes in economic growth (Nyangena 2016). The findings of earlier studies revealed that temperature variability had an inverse relationship with economic growth (e.g., Colacito et al. 2019; Dell et al. 2012) whereas Nyangena (2016) found a positive relationship between temperature and economic growth. Nyangena (2016) determined the long-run relationship between economic growth and weather and used a vector error correction model to analyze the impact of weather variability on economic growth. On the other hand, this research aims to analyze the effect of weather variability on 13 different sectors in the Kenyan economy as opposed to the economy at an aggregate level. The sectors included in this research are: agriculture and forestry; mining and quarrying; manufacturing; electricity and water; construction; wholesale and retail trade; hotels and restaurants; transport and communication; financial intermediation; real estate, renting, and business services; public administration; education; and other services. Additionally, this chapter will also provide insight as to whether there is a long-run relationship between weather variability and output from the 13 sectors that contribute to Kenya's overall economic growth.

\section{Interactions Between the Variables Used in This Research}

The dependent variable in this research was sectoral output (measured using GDP per sector) focusing on the following sectors: agriculture and forestry; mining and quarrying; manufacturing; electricity and water; construction; wholesale and retail trade; hotels and restaurants; transport and communication; financial intermediation; real estate, renting and business services; public administration; education; and other services. The sectors were chosen based on availability of historical information. GDP per sector is the contribution that the sector has on overall GDP. The independent variables were temperature, rainfall, gross fixed capital formation, labor, and the business regulatory environment captured using the country policy and institutional assessment (CPIA) (Fig. 1).

The Cobb-Douglas function drives the concept behind the variables chosen. Labor and capital should have a positive relationship with output, and in this case, the sectoral output is expected to have a positive relationship with gross capital formation because increased investments are expected to increase production and as 


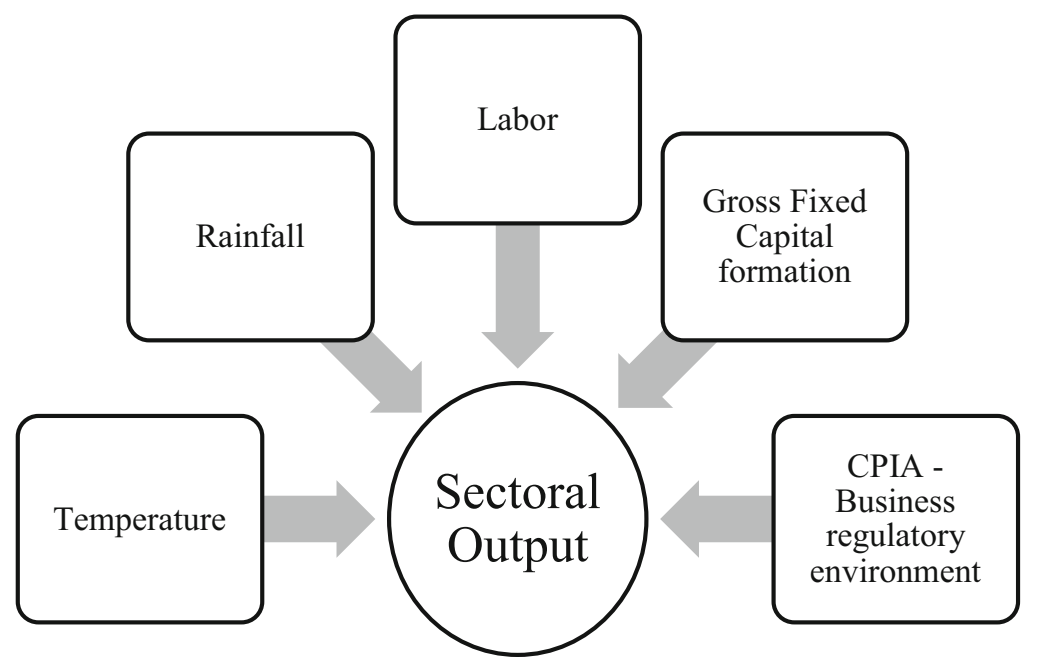

Fig. 1 Interactions between the variables used in this research

such there would be more output, which is plowed back to investments and the cycle continues. The CPIA rating is expected to have a positive relationship with sectoral output where policy improvements would positively impact output growth. Labor is also expected to have a positive relationship with sectoral output because the labor force is key to increasing productivity up to a certain level. An increase in productivity due to labor just like capital formation should result in an increase in output, which would be eventually plowed back as investments, which could take the form of increased labor opportunities. The weather variables (rainfall and temperature) on the other hand are expected to have an inverse relationship with sectoral output should there be a significant increase or decrease. For example, in the case of agriculture, a significant increase or decrease in temperature and/or rainfall will affect agricultural yield, reducing production and in the long-run causing a decline in output, which is GDP per sector in this case.

\section{Approach to Identify the Relationship Between Weather Variability and Sectoral Output}

\section{Data Collected}

This research sought to determine the effect of temperature and rainfall on sectoral output in Kenya and further establish if there is a long-run relationship between temperature, rainfall, and sectoral output in Kenya. This research studied the sample overtime using past information, which made it possible to establish the direction and magnitude of the effect of the independent variables on the dependent variable.

According to the data availability on Kenya National Bureau of Statistics, the Kenyan economy has 13 economic sectors. The major industries include agriculture, 
forestry, fishing, mining, manufacturing, energy, tourism, and financial services. For this chapter, data on all 13 economic sectors over a period of 10 years, from 2008 to 2017 was used to establish the effect of weather variability on the economy. To capture the effects of weather variability of economic sectors in Kenya, the start year of the research was 2008 but due to the unavailability of the most recent data on weather in Kenya, this research was limited to the years 2008-2017. Weather is generally described using the following atmospheric conditions: Temperature, wind, precipitation, and sunlight. Being in the tropics (at the equator) precipitation is generally experienced as rainfall and as such, due to limited data, the variables used to measure weather variability in this chapter are rainfall and temperature over a period of 10 years from 2008 to 2017.

The data used was collected from secondary sources and comprised observations of variables over time with a cross-sectional dimension based on economic sectors. As such, panel data was used for this research. Variables used were temperature in degrees Celsius, rainfall in millimeters, GDP per sector in local currency, gross fixed capital formation in local currency, labor, and CPIA. The data for temperature in degrees Celsius, rainfall in millimeters were obtained from the World Bank Climate Change portal. Data for GDP per sector in local currency were obtained from the Kenya National Bureau of Statistics. Gross fixed capital formation data in local currency, which was measured as the annual net increase in physical assets was obtained from the World Bank Development Indicators. The data for labor, which measures the number of people employed was also obtained from the World Bank Development Indicators, while the CPIA data, which measures the implication of the legal, regulatory, and policy environments that help or hinder private businesses in investing, creating jobs, and becoming more productive was obtained from the World Bank Country Policy and Institutional Assessment database. All variables used for this research had an annual frequency.

\section{Model on the Relationship Between Weather Variability and Sectoral Output}

A panel data model was estimated and used to analyze the data. This model was used to provide information on the effect of temperature and rainfall on sectoral output in Kenya and was estimated using the fully modified ordinary least squares (FMOLS) method. All the variables were transformed into natural logarithms thus allowing the coefficient estimates to be interpreted as elasticities. The dependent variable of the model was GDP per sector (sectoral output) defined as the share that each sector contributes toward GDP. The independent variables were temperature measured in degrees Celsius and rainfall in millimeters. Additionally, following the Cobb-Douglas function of measuring productivity, the gross fixed capital formation was included to account for capital and labor force was used to account for human capital. The business regulatory environment was also captured using the country policy and institutional assessment (CPIA). Below is the econometric model: 


$$
\begin{aligned}
\ln G D P \text { per sector } & =\beta_{0}+\beta_{1} \operatorname{lnCapital~formation~}_{i t}+\beta_{2} \operatorname{lnLabor~}_{i t}+\beta_{3} \operatorname{lnTemp}_{i t} \\
& +\beta_{4} \operatorname{lnRain}_{i t}+\beta_{5} \operatorname{lnCPIA}_{i t}+\omega_{i t}
\end{aligned}
$$

Where: $\beta_{0}$ is the intercept, which is the same for all the sectors and over time. $\beta_{1}$ to $\beta_{5}$ are slope parameters. The subscript $i$ refers to an individual sector and $t$ refers to the years from 2008 to 2017. $\omega_{i t}=\varepsilon_{\mathrm{i}}+u_{i t}$. $\varepsilon_{\mathrm{i}}$ measures the random deviation of each sector's intercept from the common intercept term $\beta_{0}$ and $u_{i t}$ is the residual term for sector $i$ at time $t$. Capital formation is the net increase in physical assets, Labor captures the number of people employed, Temp captures temperature in degrees Celsius, Rain captures rainfall in millimeters, and CPIA captures the business regulatory environment as a rating $(1=$ low to $6=$ high $)$.

\section{Procedure}

Before investigating the existence of a long-run relationship between weather variability and sectoral output, a unit root test was carried out. Unit root tests are used to find out if a series of variables is stationary or nonstationary. When a series is stationary, the variables are time-invariant and are better suited for making forecasts. This research employed the Im, Peseran, and Shin (IPS) unit root test. Next, a test for the existence of a long-run relationship between weather variability and sectoral output using a cointegration test was carried out. A panel cointegration approach was employed and the principal idea was to investigate the existence of a long-run relationship among the nonstationary variables. Finally, a fully modified ordinary least squares (FMOLS) procedure was adopted to estimate the effect of weather variability on sectoral output. Pedroni (1996) brings forth the FMOLS as a solution to tackling non-exogeneity and serial correlation problems. Additionally, FMOLS addresses the problem of nonstationary variables as well as simultaneity biases.

\section{Establishing the Relationship Between Weather Variability and Sectoral Output}

\section{Unit Root Test}

In order to establish whether the distribution of the variables used in this research does not change with time (stationarity), unit root tests were carried out. The results in Table 1 are a result of conducting an Im, Pesaran, and Shin (IPS) panel unit root test at level, first difference, and second difference. When conducting a unit root test, the null hypothesis is the presence of a unit root and rejecting the null means that the variable is stationary. The null hypothesis is rejected when the p-value is smaller than $0.05(p<0.05)$. At level, the null hypothesis is rejected for rainfall and CPIA indicating stationarity. At first difference, the null hypothesis is rejected for GDP per sector and capital formation and finally, at second difference, the null hypothesis is rejected for temperature and labor. 
Table 1 Unit root test results

\begin{tabular}{l|l|l|l}
\hline Variable & Level & First-order difference & Second-order difference \\
\hline GDP per sector & $-0.4362(1.000)$ & $-2.8004^{\mathrm{a}}(0.0001)$ & \\
\hline Temperature & $0.2327(1.000)$ & $-2.4535(0.2990)$ & $-2.3519^{\mathrm{a}}(0.0022)$ \\
\hline Rainfall & $-3.8568^{\mathrm{a}}(0.0000)$ & & \\
\hline Capital formation & $-1.5808(0.1887)$ & $-3.2164^{\mathrm{a}}(0.0000)$ & \\
\hline Labor & $-0.8516(0.9791)$ & $-0.5463(0.9995)$ & $-3.0059^{\mathrm{a}}(0.0000)$ \\
\hline CPIA & $-2.3886^{\mathrm{a}}(0.0010)$ & & \\
\hline
\end{tabular}

$\mathrm{P}$-values in parenthesis

${ }^{a}$ Statistically significant at the $5 \%$ level of significance

Table 2 Panel cointegration results

\begin{tabular}{l|l}
\hline Test & Level \\
\hline Modified Phillips-Perron test & $3.0714^{\mathrm{a}}(0.0011)$ \\
\hline Phillips-Perron & $1.9829^{\mathrm{a}}(0.0237)$
\end{tabular}

P-values in parenthesis

${ }^{\text {a }}$ Statistically significant at the $5 \%$ level of significance

\section{Long-Run Relationship Between Temperature and Sectoral Output}

Next, cointegration was tested. This test was used to find out if there exists a longrun relationship between sectoral output and temperature. Rainfall is not taken into account in this test as it is a stationary variable at level. The p-values in Table 2 are the values in parenthesis and are highlighted by an asterisk at a $95 \%$ confidence level. Given that the $\mathrm{p}$-values of the cointegration tests are less than $0.05(p<0.05)$, the null hypothesis of no cointegration is rejected. This result indicates that there is a long-run relationship between sectoral output and temperature, which answers the research objective of establishing if there is a long-run relationship between weather variability and sectoral output in Kenya. The long-run relationship between the temperature and sectoral output supports the findings of Nyangena (2016) who found that weather and output in Kenya had a long-run relationship.

\section{Effect of Weather Variability on Sectoral Output}

After establishing the presence of a long-run relationship between sectoral output and temperature, a method known as fully modified ordinary least squares (OLS) was used to establish the relationship between weather variability and sectoral output. The results of the estimation are shown in Table 3.

The results in Table 3 show that there is a negative effect of temperature in degree Celsius on sectoral output, where a $1 \%$ increase in temperature leads to a $4.02 \%$ decrease in sectoral output holding all other factors constant. Regarding rainfall in millimeters, there is a positive relationship with sectoral output where a $1 \%$ increase in rainfall would result in a $0.19 \%$ increase in sectoral output holding all other factors 
Table 3 Fully modified ordinary least squares results

\begin{tabular}{l|l|l|l}
\hline Variable & Coefficient & P-value & Standard error \\
\hline Temperature & -4.0229 & 0.7086 & 10.7312 \\
\hline Rainfall & 0.1920 & 0.6976 & 0.4927 \\
\hline CPIA & 0.7531 & 0.7624 & 2.4837 \\
\hline Capital formation & -0.8404 & 0.4746 & 1.1710 \\
\hline Labor & $8.2220^{\mathrm{a}}$ & 0.0102 & 3.1398 \\
\hline
\end{tabular}

${ }^{a}$ Statistically significant at the $5 \%$ level of significance

constant. Colacito et al. (2019) also found an increase in temperature resulted in possible declines in economic growth. As seen in this chapter, there also exists an inverse relationship between temperature and sectoral output. Moreover, the inverse relationship between temperature and sectoral output is of a higher magnitude in comparison to the relationship between rainfall and sectoral output. This is consistent with the findings of Ochieng et al. (2016) who reported that temperature has a bigger effect on crop production in Kenya than rainfall. This chapter also supports the findings of Van-Passel et al. (2012) who argued that agricultural output is positively affected by rainfall when received on season and is good for overall economic performance. Even though this chapter found that rainfall has a positive effect on sectoral output, one should also keep in mind that continued heavy rain is likely to cause economic losses in Kenya as revealed by Ngecŭ and Mathu (1999) in their research. This research cannot particularly rule out this effect as it does not consider the seasonality of weather and the shocks therein.

The business regulatory environment as measured by the Country Policy and Institutional Assessment (CPIA) has a positive relationship with sectoral output where a $1 \%$ increase in the CPIA rating would result in an increase of sectoral output by $0.75 \%$ holding all other factors constant. The findings of this chapter also support the research carried out by Kimenyi et al. (2016) who reported that policy improvement would result in economic transformations and sustained economic growth in the sectors in Kenya.

Additionally, labor, which is the number of people employed, also has a positive relationship with sectoral output. A $1 \%$ increase in labor would result in an $8.22 \%$ increase in sectoral output holding all other factors constant. These results support the findings of Kimenyi et al. (2016) who found a positive correlation between human capital and productivity growth in Kenya. Further, they discuss the role of investment in education to improve the quality of human capital and spur rapid economic growth in the country.

Finally, capital formation and sectoral output have a negative relationship where a $1 \%$ increase in capital formation results in a $0.84 \%$ decrease in sectoral output holding all other factors constant. These results are different from the analysis carried out by Ongo et al. (2014) who find that technical progress and infrastructural development have a positive association with economic growth in the Economic and Monetary Community of Central Africa. Interestingly, the findings from Zeb (2013) indicate that the quality of capital falls as temperature increases and results in a drop 
in economic growth. With the exception of labor, all other variables in the model are not statistically significant. This indicates that weather variability in Kenya does not have a significant direct impact on sectoral output in the country. However, the annual nature of the data used in this research meant that the seasonal effects of weather variability on sectoral output were not captured, which may have led to the weather variables being statistically insignificant. Due to the unavailability of quarterly data (labor, gross fixed capital formation, and CPIA - business regulatory environment), this chapter was unable to take into account the seasonal effects of these variables.

\section{Conclusion}

The results from this chapter indicate the presence of a long-run relationship between sectoral output in Kenya and temperature. Furthermore, there is an inverse relationship between temperature and sectoral output, which shows that an increase in temperature will lead to a decrease in sectoral output in Kenya. On the other hand, this research finds a positive relationship between rainfall and sectoral output, which reveals that an increase in rainfall in the country is likely to lead to an increase in GDP per sector. Kenya's economy is highly reliant on the agricultural sector with most small-scale farmers relying on rain-fed farming. As such, an increase in consistent rainfall will lead to increased agricultural output as long as the rainfall is not in excess. Additionally, findings from this chapter show that the business regulatory environment as measured by the World Bank CPIA rating has a positive relationship with sectoral output. This implies that a better policy and institutional framework will lead to higher output in the various sectors in Kenya. The number of people employed also has a positive relationship with sectoral output. Gross fixed capital formation, which measures the annual net increase in physical assets has a negative relationship with GDP per sector in Kenya.

With the evidence gathered from this research, it can be concluded that weather variability has an economic effect on output from the different sectors in Kenya. This suggests that the Kenyan government needs to take a keen interest in understanding and addressing the effects of weather variability and in a broader picture, the effect of climate change on each sector of economy. Some of the sectors may bear more of the brunt due to their dependent nature on weather. However, none of the sectors in the Kenyan economy will be left unaffected due to the effects of changing weather patterns and in the long term, climate change. Therefore, the Kenyan government should ensure that it fully supports the National Adaptation Plan, which is supported by the Climate Change Act that was enacted into law in May 2016. Additional support and increased partnerships will also be required for Kenya to achieve its climate adaptation goals. For example, Kenya needs to actively take a broader perspective that encompasses other countries including those outside the African continent in its environmental conservation discussions. This is because the impact of climate change affect all countries across the globe. As much as temperature and rainfall levels in Kenya are not at extreme levels, there has been a notable change in 
the weather patterns and the effects are starting to be felt. Given this, Kenya should consider being more aggressive in its reforestation campaign throughout the country. This will help to remove excess carbon dioxide emissions from the atmosphere, thus reducing the severity of weather pattern changes and in the long-run, mitigate climate change. Further research could be carried out to investigate the effect of weather variability on the Kenyan economy using data with a higher frequency. This would help to factor in the effect of climatic seasons in the country on the economy.

\section{References}

Abidoye B, Odusola A (2015) Climate change and economic growth in Africa: an econometric analysis. J Afr Econ 25:1-25. https://doi.org/10.1093/jae/eju033

Awuor C, Orindi V, Adwera O (2008) Climate change and coastal cities: the case of Mombasa, Kenya. Environ Urban 20:231-242

Barro R (1999) Determinants of economic growth: implication of the global evidence for Chile. Cuad Econ 36(107):443-478

Colacito R, Hoffmann B, Phan T (2019) Temperature and growth: a panel analysis of the United States. JMCB 51:313-368. https://doi.org/10.1111/jmcb.12574

Dell M, Jones B, Olken B (2012) Temperature shocks and economic growth: evidence from the last half century. Am Econ J Macroecon 4:66-95

Deryugina T, Hsiang S (2014) Does the environment still matter? Daily temperature and income in the United States. NBER Working Paper (No. w20750; w20750)

Ferrara E (2015) The atlas of climate change: mapping the World's greatest challenge. University of California Press, Berkeley

Food and Agriculture Organization of the United Nations (2019) Kenya at a glance: the agriculture sector in Kenya. Retrieved from http://www.fao.org/kenya/fao-in-kenya/kenya-at-a-glance/en/

Hulme M (2009) Why we disagree about climate change. Cambridge University Press, Cambridge, UK

Idso C, Singer S (2009) Climate change reconsidered. The Heartland Institute, Chicago

Intergovernmental Panel on Climate Change (2014) Summary for policymakers. Contribution of working group II to the fifth assessment report of the intergovernmental panel on climate change. Cambridge University Press, New York

Kimenyi M, Mwega F, Ndung'u N (2016) Kenya economic growth, labor market dynamics, and prospects for a demographic dividend. In: Bhorat H, Tarp F (eds) Africa's lions: growth traps and opportunities for six African economies. Brookings Institution Press, Washington, DC, pp 4, 109-4, 144

Linke M, O'Loughlin J, McCabe T, Tir J, Witmer F (2015) Rainfall variability and violence in rural Kenya: investigating the effects of drought and the role of local institutions with survey data. Glob Environ Chang 34:35-47

Lorenz EN (1963) Deterministic nonperiodic flow. J Atmos Sci 20:130-141

Matsui T, Pielke RA (2006) Measurement based estimation of the spatial gradient of aerosol radiative forcing. Geospatial Res Lett 33:L11813

Montesquieu B, De Secondat C (1748) The spirit of laws. Batoche books: Kitchener, London

Mortimore M, Anderson S, Cotula L, Davies J, Faccer K, Hesse C, Wolfangel C (2009) Dryland opportunities: a new paradigm for people, ecosystems and development. International Union for Conservation of Nature and Natural Resources (IUCN), Gland

National Centers for Environmental Information (NCEI) (2018) http://www.ncei.noaa.gov/news/ weather-vs-climate. Accessed 14 Mar 2020

Ngecŭ WM, Mathu EM (1999) The El-Nino-triggered landslides and their socioeconomic impact on Kenya. Environ Geol 38(4):277-284 
Nordhaus WD (2010) The economics of hurricanes and implications of global warming. Clim Change Econ 1:1-20

Nyangena OM (2016) The impact of weather variability on economic growth in Kenya. University of Nairobi Press. https://papers.ssrn.com/sol3/papers.cfm?abstract id=3161257

Ochieng J, Kirimi L, Mathenge M (2016) Effects of climate variability and change on agricultural production: the case of small scale farmers in Kenya. NJAS - Wageningen J Life Sci 77:71-78

Okaka FO, Odhiambo BDO (2018) Relationship between flooding and out break of infectious diseases in Kenya: a review of the literature. J Environ Public Health. https://doi.org/10.1155/ 2018/5452938

Okoba B, Bryan E, Ringler C, Roncoli C, Silvestri S, Herrero MT (2013) Adapting agriculture to climate change in Kenya: household strategies and determinants. J Environ Manag 114:26-35

Ongo NB, Vukenkeng AW, Seppo MP (2014) Mechanisms of the influence of human capital on economic growth: a panel data analysis of CEMAC region. Asian Econ Financ Rev 4(5):625640

Opere A (2013) Floods in Kenya. In: Paron P, Olago DO, Omuto CT (eds) Developments in earth surface processes. Elsevier, Oxford

Pedroni P (1996) Fully modified OLS for heterogeneous cointegrated panels and the case of purchasing power parity. Working paper in Economics 96(020). https://web.williams.edu/ Economics/pedroni/WP-96-20.pdf

Smith A (1776) An inquiry into the nature and causes of the wealth of nations. (Cannan ed.) https:// oll.libertyfund.org/titles/smith-an-inquiry-into-the-nature-andcauses-of-the-wealth-of-nationscannan-ed-vol-1

Smith L (2002) What might we learn from climate forecasts? USA: Proc Natl Acad Sci 99(Suppl 1):2487-2492

Stephens G, Li JL, Wild M, Clayson C, Loeb N, Kato S, Andrews T (2012) An update on Earth's energy balance in light of the latest global observations. Nat Geosci 5(10):691-696

Sud Y, Walker G, Lau W (1999) Mechanisms regulating sea-surface temperatures and deep convection in the tropics. Geophys Res Lett 26(8):1019-1022

U.S. Global Change Research Program (2014) Global change. Retrieved from Extreme weather: https://nca2014.globalchange.gov/highlights/report-findings/extreme-weather

Van Passel S, Massetti E, Mendelson RO (2012) A ricardian analysis of the impact of climate change on european agriculture. Nota Di Lavoro, 83

World Bank (2012) Turn down the heat: why a 4C warmer world must be avoided. Potsdam Institute for Climate Impact Research and Climate Analytics. https://openknowledge. worldbank.org/handle/10986/11860

World Health Organization (2018, November 7) Climate change increases risk of outbreaks in Africa. Retrieved from WHO Africa: https://www.afro.who.int/news/climate-change-increasesrisk-outbreaks-africa

Yanda PZ, Mubaya CP (2011) Managing a changing climate in Africa: local level vulnerabilities and adaptation experiences. African Books Collective. http://www.africanbookscollective.com/ books/managing-a-changing-climate-in-africa

Zeb A (2013) Climate change and economic growth in Nordic countries: an application of smooth coefficient semi-parametric approach. Int J Soc Sci 11(3):159-171

Zivin J, Neidell M (2014) Temperature and the allocation of time: implications for climate change. J Labor Econ 32(1):1-26 
Open Access This chapter is licensed under the terms of the Creative Commons Attribution 4.0 International License (http://creativecommons.org/licenses/by/4.0/), which permits use, sharing, adaptation, distribution and reproduction in any medium or format, as long as you give appropriate credit to the original author(s) and the source, provide a link to the Creative Commons license and indicate if changes were made.

The images or other third party material in this chapter are included in the chapter's Creative Commons license, unless indicated otherwise in a credit line to the material. If material is not included in the chapter's Creative Commons license and your intended use is not permitted by statutory regulation or exceeds the permitted use, you will need to obtain permission directly from the copyright holder.

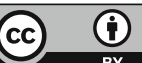

